\title{
Spatio-temporal sensitivity of MODIS land surface temperature anomalies indicates high potential for large-scale land cover change detection in Arctic permafrost landscapes
}

\author{
S. Muster ${ }^{\mathrm{a}, *}$, M. Langer ${ }^{\mathrm{a}}$, A. Abnizova ${ }^{\mathrm{b}}$, K.L. Young $^{\mathrm{b}}$, J. Boike $^{\mathrm{a}}$ \\ a Alfred Wegener Institute for Polar and Marine Research, Telegrafenberg A43, 14473 Potsdam, Germany \\ b Geography Department, York University, Toronto, Ontario M3J 1P, Canada
}

\section{A R T I C L E I N F O}

\section{Article history:}

Received 15 September 2014

Received in revised form 28 May 2015

Accepted 19 June 2015

Available online xxxx

\section{Keywords:}

Land surface temperature

LST

MODIS

Land cover

Albedo

Surface soil moisture

Topography

Anomaly

Change detection

Monitoring

Remote sensing

Surface energy balance

Permafrost

Tundra

Polar desert

Canadian High Arctic

\begin{abstract}
A B S T R A C T
The accelerated warming of the Arctic climate may alter the local and regional surface energy balances, for which changing land surface temperatures (LSTs) are a key indicator. Modeling current and anticipated changes in the surface energy balance requires an understanding of the spatio-temporal interactions between LSTs and land cover, both of which can be monitored globally by measurements from space. This paper investigates the accuracy of the MODIS LST/Emissivity Daily L3 Global $1 \mathrm{~km}$ V005 product and its spatio-temporal sensitivity to land surface properties in a Canadian High Arctic permafrost landscape. The land cover ranged from fully vegetated wet sedge tundra to barren rock. MODIS LSTs were compared with in situ radiometer measurements from wet tundra areas collected over a 2-year period from July 2008 to July 2010 including both summer and winter conditions. The accuracy of the MODIS LSTs was $-1.1{ }^{\circ} \mathrm{C}$ with a root mean square error of $3.9^{\circ} \mathrm{C}$ over the entire observation period. Agreement was lowest during the freeze-back periods where MODIS LST showed a cold bias likely due to the overrepresentation of clear-sky conditions. A multi-year analysis of LST spatial anomalies, i.e., the difference between MODIS LSTs and the MODIS LST regional mean, revealed a robust spatiotemporal pattern. Highest variability in LST anomalies was found during freeze-up and thaw periods as well as for open water surface in early summer due to the presence or absence of snow or ice. The summer anomaly pattern was similar for all three years despite strong differences in precipitation, air temperature and net radiation. Summer periods with regional mean LSTs above $5.0^{\circ} \mathrm{C}$ showed the greatest spatial diversity with four distinct $2.0^{\circ} \mathrm{C}$ classes. Summer anomalies ranged from $-4.5^{\circ} \mathrm{C}$ to $2.6{ }^{\circ} \mathrm{C}$ with an average standard deviation of $1.8^{\circ} \mathrm{C}$. Dry ridge areas heated up the most, while wetland areas and dry areas of sparsely vegetated bedrock with a high albedo remained coolest. The observed summer LST anomalies can be used as a baseline against which to evaluate both past and future changes in land surface properties that relate to the surface energy balance. Summer anomaly classes mainly reflected a combination of albedo and surface wetness. The potential to use this tool to monitor surface drying and wetting in the Arctic should therefore be further explored. A multi-sensor approach combining thermal satellite measurements with optical and radar imagery promises to be an effective tool for a dynamic, process-based ecosystem monitoring scheme.
\end{abstract}

(c) 2015 Elsevier Inc. All rights reserved.

\section{Introduction}

Arctic land surface temperatures are increasing twice as rapidly as global temperatures, as has been indicated by measurements both on the ground (ACIA, 2005; AMAP, 2011; Hinzman, Bettez, \& Bolton, 2005; Parry, 2007) and from space (Comiso, 2003, 2006). Land surface warming results in associated changes in land surface properties, especially in areas underlain by permafrost. The thawing of ground ice in permafrost soils causes the ground to subside and lake shorelines to erode. As a consequence, surface wetting is observed due to the

\footnotetext{
* Corresponding author.

E-mail address: sina.muster@awi.de (S. Muster).
}

expansion of lakes and the formation of new ponds (Jorgenson, Racine, Walters, \& Osterkamp, 2001; Jorgenson, Shur, \& Pullman, 2006; Smith, Sheng, MacDonald, \& Hinzman, 2005; Watts, Kimball, Jones, Schroeder, \& McDonald, 2012). The thawing of ground ice may also lead to surface drying as a result of lake drainage (Carroll, Townshend, DiMiceli, Loboda, \& Sohlberg, 2011; Smith et al., 2005; Yoshikawa \& Hinzman, 2003). Current climate projections of the Arctic predict even more dramatic changes in land surface properties. This includes the spread of shrub and forest at the expense of tundra (Matthes et al., 2012) with associated changes in albedo (Chapin, Sturm, \& Serreze, 2005; Sturm, Racine, \& Tape, 2001) that are expected to amplify temperature changes over land (Euskirchen et al., 2007; Hinzman et al., 2013). Such land cover changes also affect other biogeophysical surface 
properties, such as soil moisture, emissivity, and surface roughness, all of which regulate the surface energy balance, i.e., the partitioning of the available net radiation into the sensible and latent heat flux and the ground heat flux (Hinzman et al., 2013). Radiometric land surface temperatures (LSTs) are dependent on the surface energy balance and reflect the combined effects of land surface properties and atmospheric conditions, which together control the transfer of energy into either the atmosphere or the ground (Dickinson, 1983; Friedl, 2002; Jin \& Dickinson, 2010; Mannstein, 1987). LST is therefore a key parameter for both modeling and monitoring the surface energy balance.

Satellite-borne thermal sensors provide access to LSTs over large areas. This is especially invaluable in the vast and remote Arctic landscapes, where ground-based observations of LSTs are sparse. Sensors such as the Landsat and ASTER sensors provide medium resolutions of $90 \mathrm{~m}$, but are limited in both areal coverage and temporal resolution. Sensors with global coverage, such as the Moderate Resolution Imaging Spectroradiometer (MODIS) have a limited spatial resolution of $1 \mathrm{~km}$ or more but a high temporal resolution, with several measurements per day in the Polar Regions. MODIS LSTs provide a versatile tool that can be used for both modeling and monitoring applications which are essential for assessing and anticipating changes in the hydrology, ecology, and climatology of Arctic ecosystems. The use of MODIS LSTs for permafrost modeling in the Arctic has been demonstrated by Langer, Westermann, and Boike (2010), Westermann, Langer, and Boike (2011), and Langer, Westermann, Heikenfeld, Dorn, and Boike (2013). Other studies successfully used MODIS LST to monitor changes in vegetation and land cover (Bhatt et al., 2013; Coops, Wulder, \& Iwanicka, 2009; Zhang, Friedl, Schaaf, \& Strahler, 2004).

The interpretation of LST changes in Arctic environments in terms of the surface energy balance requires an understanding of the relationship between the measurement uncertainty in LSTs and their spatiotemporal sensitivity. Efforts have recently increased to quantify LST uncertainty in the high latitudes by consolidating LST data sources (Soliman, Duguay, Saunders, \& Hachem, 2012) and by comparing LSTs to ground and air temperatures over large regions, including herbaceous and shrub tundra sites in northern Quebec, Canada, and on the North Slope of Alaska, USA (Hachem, Duguay, \& Allard, 2012). Comparisons have also been made with in situ radiometer measurements at a polygonal tundra site in Siberia (Langer et al., 2010), at a barren site (Westermann, Langer, \& Boike, 2011, 2012) and an Arctic ice cap on Svalbard (Østby et al., 2014). Few case studies have attempted to elaborate the specific relationship between land surface characteristics and remotely sensed LSTs in Arctic environments, where permafrost plays a crucial role in the surface energy balance. Those that have were conducted at diverse temporal and spatial scales. Regional surface thermal patterns have been investigated in relation to the Normalized Difference Vegetation Index (NDVI), land cover, and elevation in boreal and tundra landscapes of northern Canada, but only for single snapshots in summer (Bussières, 2002; Gota, Royer, \& Bussières, 1997). Langer et al. (2010) and Westermann et al. (2011) discussed the effect of net radiation and surface soil moisture on MODIS LSTs over the course of a summer season in Siberian ice-wedge polygonal tundra and at a barren site on Svalbard, but their investigations were spatially restricted to a single MODIS pixel.

In this study we have evaluated the use of MODIS LSTs to detect large-scale land surface changes in an Arctic permafrost tundra landscape. To this end, a two year record of MODIS LSTs for Bathurst Island, in the Canadian High Arctic, has been evaluated. The study area includes a broad range of typical Arctic land cover types, ranging from fully vegetated wet sedge tundra to barren rock areas. Specific objectives of the study were (i) to validate the performance of the MODIS LST/Emissivity Daily L3 Global $1 \mathrm{~km}$ V005 product against in situ radiometer measurements, (ii) to investigate the spatial and temporal relationships between MODIS LSTs and land surface properties, and (iii) to assess the sensitivity of MODIS LSTs with regard to land cover change detection.

\section{Study area}

Bathurst Island $\left(98^{\circ} 30^{\prime} \mathrm{W}, 75^{\circ} 40^{\prime} \mathrm{N}\right)$ is located in the central zone of the Canadian Arctic Archipelago in Nunavut, Canada (Fig. 1a). It has a typical polar desert climate with long, cold winters and short, cool summers (Young \& Labine, 2010). The climate does not significantly differ from the climate at Resolute Bay on Cornwallis Island, which lies about $145 \mathrm{~km}$ to the southeast, where long-term climate records are available dating back to 1948 . The mean January air temperature is $-32.2{ }^{\circ} \mathrm{C}$ in Resolute Bay and the mean July air temperature is $4.3^{\circ} \mathrm{C}$ (downloaded from http://climate.weather.gc.ca/). The mean annual precipitation for the years 1948 to 2007 is about $159 \mathrm{~mm}$ (Mekis \& Vincent, 2011). Air temperatures have been warming at both Resolute Bay and Polar Bear Pass over the last decade (Woo \& Young, 2014).

In low-lying areas the underlying permafrost impedes drainage which results in poorly drained, highly saturated soils (Woo \& Young, 2006). These wetland and wet sedge tundra areas support unusually productive habitats with a plant cover of $65 \%$ or more in the otherwise dry and barren environment. One of the largest continuous areas of wetland on the island is Polar Bear Pass (PBP), which has a surface area of about $94 * 10^{6} \mathrm{~m}^{2}$ and is located in the study area (Fig. 1c). PBP has been designated a National Wildlife Area by the Canadian Wildlife Service as well as a waterfowl habitat of international importance according to the Ramsar Convention (http://www.ramsar.org/). It is a crucial staging area for migratory birds and also a bird breeding area. It serves as a key travel route for polar bears during spring and summer and is a vital habitat for muskoxen and caribou. The PBP wetland area is bordered by hills that reach about $240 \mathrm{~m}$ above sea level; runoff from these hillslopes supplies both water and sediment into the adjacent wetland area (Woo \& Young, 2006). Within the wetland zone, moss, grass, and sedge meadows alternate with sparsely vegetated dry ridges and numerous small ponds and lakes, creating a patchy land cover pattern. Plant growth is limited to the short snow-free season which typically lasts from mid-June to the end of August. Soil conditions and plant communities reflect the local water supply (Edlund \& Alt, 1989; Nettleship \& Smith, 1975; Sheard \& Geale, 1983). Uplands and plateaus are comparatively dry with a low total plant cover; plant communities in these areas consist of scattered herbaceous perennials with varying amounts of lichen (Sheard \& Geale, 1983).

\section{Methods}

\subsection{Measuring in situ LST and climate data}

In situ LST measurements were recorded using a Precision Infrared Temperature Sensor (IRTS-P, Apogee Instruments) over wet sedge tundra (Fig. 2). The sensor was mounted $0.83 \mathrm{~m}$ above the canopy, with a field of view of about $0.28 \mathrm{~m}$ in diameter. The IRTS-P had an accuracy of $\pm 0.5{ }^{\circ} \mathrm{C}$ in the range of -40 to $80^{\circ} \mathrm{C}$. In situ LST measurements were recorded from July 2008 to July 2010 . Battery failure led to a measurement gap between July 13 and July 21, 2009, July 17 and July 21, 2010 as well as between December 23, 2009 and April 27, 2010.

An automatic weather station was set up a few meters from the radiometer station and recorded net radiation, incoming short-wave radiation, and air temperature over the same time period as the in situ LST measurements. Net radiation and incoming short-wave radiation were measured with a NR Lite (Kipp \& Zonen) with an accuracy of $0.01 \mathrm{MJ} \mathrm{m}^{-2}$. The air temperature was measured with a CS215 temperature probe (Campbell Scientific, Inc.), which had an accuracy of $\pm 0.2^{\circ} \mathrm{C}$. The total daily precipitation was recorded from the beginning of June to the end of August, using a tipping bucket rain gauge (Campbell Scientific, Inc.) with an accuracy of $\pm 0.25 \mathrm{~mm}$. During summer, sky condition was classified visually twice daily and served as a qualitative measure with which to characterize distinct synoptic periods. We distinguished between snow-covered and snow-free 


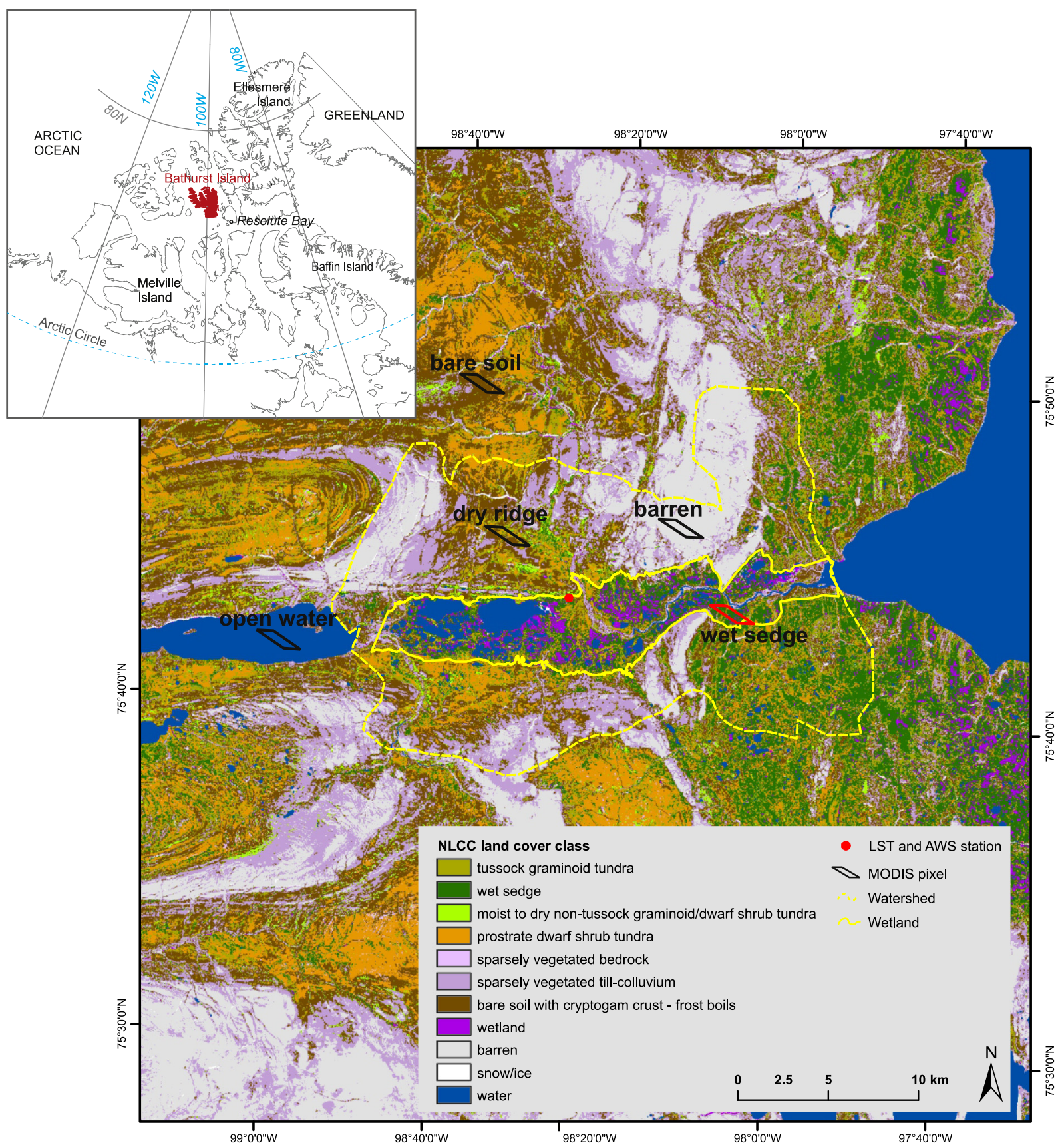

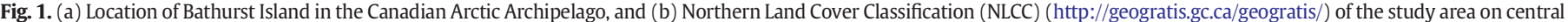

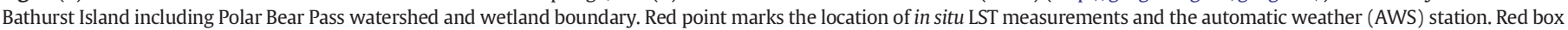

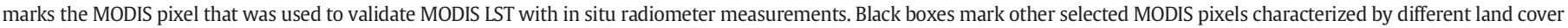
types. (For interpretation of the references to color in this figure legend, the reader is referred to the web version of this article.)

periods based on field observations made by Assini and Young (2012).

\subsection{Evaluating MODIS LSTS}

MODIS LSTs were acquired from the MODIS LST/Emissivity Daily L3 Global $1 \mathrm{~km}$ V005 product. Data was obtained from both the Terra (MOD11A1) and Aqua (MYD11A1) satellites and downloaded from http://reverb.echo.nasa.gov/. The MODIS LSTs are derived from measurements in the thermal infrared channels 31 (10.78 to $11.28 \mu \mathrm{m})$ and 32 ( 11.77 to $12.27 \mu \mathrm{m}$ ) using the day-night split-window algorithm (Wan \& Dozier, 1996). The maximum error is about $2{ }^{\circ} \mathrm{C}$ due to emissivity errors and uncertainty in the atmospheric correction (Wan \& Li,
1997). For the construction of the level 3 product, clear-sky LSTs in the MODIS LST level 2 product are chosen at smaller viewing zenith angles or the LSTs at larger zenith angles but their values being larger by at least $2{ }^{\circ} \mathrm{C}$ (Wan, 2006). There may be multiple MODIS level 2 observations in clear-sky conditions for latitudes beyond $30^{\circ}$ which are averaged to produce the MODIS level 3 daytime and nighttime LSTs.

MODIS LSTs were compared to in situ radiometer measurements at the closest half hour. MODIS level 3 LST data are gridded in the sinusoidal projection. Due to the conformal distortion of the sinusoidal projection at high latitudes, the grid cells over the study area are approximately $0.930 \mathrm{~km}$ wide and $1.8 \mathrm{~km}$ long. MODIS pixels show considerable subpixel heterogeneity of which MODIS LST presents an integrated signal. In situ radiometer measurements, on the other hand, 


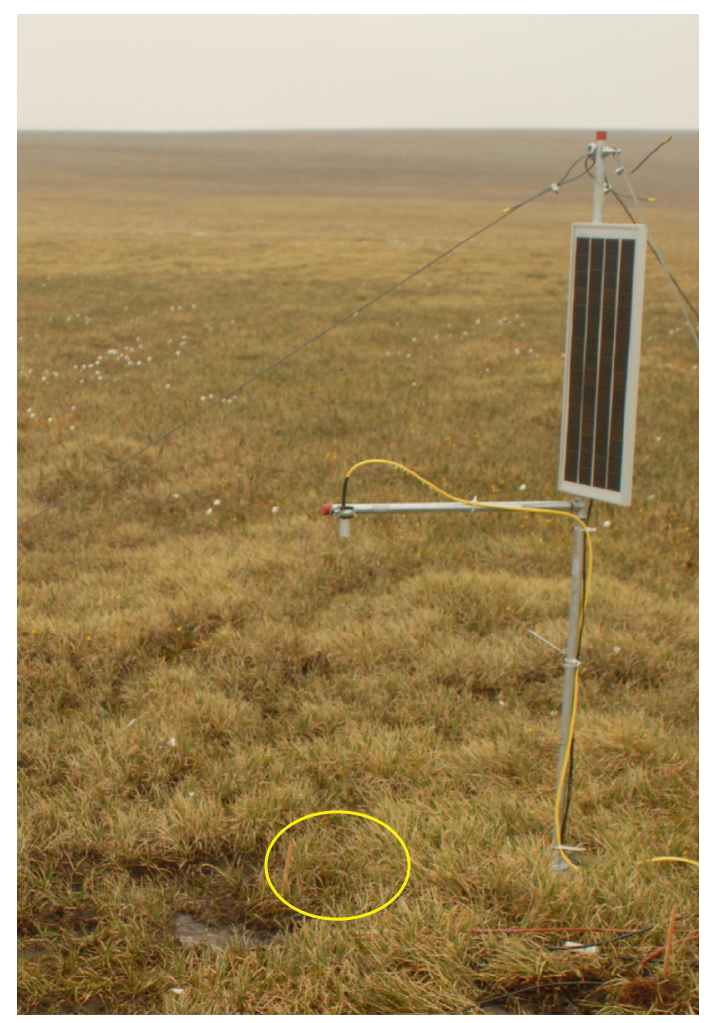

Fig. 2. Station with Precision Infrared Temperature Sensor in a zone of wet sedge tundra in the Polar Bear Pass wetland area. The yellow circle indicates the field of view of the radiometer with about $0.28 \mathrm{~m}$ in diameter. Photo shows late summer surface conditions in August, 2008. (For interpretation of the references to color in this figure legend, the reader is referred to the web version of this article.)

integrate LST over a homogeneous area of wet sedge tundra (Fig. 2). For the comparison of MODIS LST to in situ LST, a MODIS pixel was selected within the study area that contained mostly wet sedge tundra. Wet sedge tundra was identified based on the Northern Land Cover Classification (NLCC). Due to the surface heterogeneity of the wetland, the maximum proportion of wet sedge tundra within the selected MODIS pixel was 71\% (Fig. 1b). Other land cover types present in the chosen MODIS comparison pixel were wetland (6\%), tussock graminoid tundra (8\%), prostrate dwarf shrub (7\%), bare soil with sparse vegetation (3\%), water surfaces (4\%), and barren rock surfaces, i.e., non-vegetated areas of outcropping bedrock (1\%).

\subsection{Assessing MODIS LST-land surface relationships}

The Northern Land Cover Classification (NLCC) was used to assess the subpixel land cover composition of the MODIS pixels in the study area and to select approximately homogeneous MODIS pixels as being representative of different land cover types. The NLCC was derived from a Landsat-7 ETM + mosaic with a resolution of $30 \mathrm{~m}$, covering the northern part of Canada to the north of the tree line (Olthof, Butson, Fernandes, Fraser, Latifovic, \& Orazietti, 2005). Most of the imagery (including the area over Bathurst Island) was acquired during the peak of the growing season in the months of July and August, during the period from July 14, 1999 to August 28, 2002 (Olthof Latifovic, \& Pouliot, 2008). The NLCC classification identified 15 land cover classes, 12 of which are present in the study area, with an accuracy of about $85 \%$ (Olthof et al., 2008). Ponds (i.e., water bodies with a surface area smaller than $10^{4} \mathrm{~m}^{2}$ ) were not resolved by the NLCC but make up $60 \%$ of the total water bodies by number and $22 \%$ by surface area (Muster, Heim, Abnizova, \& Boike, 2013). The NLCC was therefore enhanced using a high-resolution water body classification for the PBP wetland area (Muster et al., 2013).
The MODIS grid was overlain on the NLCC in ArcGIS v10.1 (Esri) which yielded the subpixel land cover composition for each MODIS pixel in the study area. Geolocation error was $50 \mathrm{~m}$ or less for the NLCC (Olthof et al., 2008) and $50 \mathrm{~m}$ at nadir for the MODIS data (Wolfe et al., 2002). No quantitative error can be given for the spatial overlay between the two datasets due to the absence of distinctive landmarks and the coarse resolution of the MODIS data, but visual inspection revealed a reasonably good agreement (within $50 \mathrm{~m}$ ) between the shorelines of the two datasets. Four MODIS LST pixels were selected representing the dominant land cover types found in the study area, i.e., wet sedge tundra, bare soil, open water, and non-vegetated barren rock surfaces (Fig. 1b and Fig. 3). MODIS pixels composed only of barren rock surfaces could be easily identified due to the existence of large contiguous areas. However, no completely homogeneous MODIS pixels could be found for the bare soil or wet sedge classes and MODIS pixels were therefore chosen with at least $90 \%$ bare soil and with at least $71 \%$ wet sedge (Fig. $1 \mathrm{~b}$ and Table 1 ). A fifth MODIS pixel was chosen over a dry ridge where the maximum surface warming could be observed. The ridge pixel was composed of the NLCC land cover types bare soil (43\%), tussock graminoid tundra (28\%), and prostrate dwarf shrub tundra (21\%). The main lake in the PBP wetland was only partly captured by the MODIS-based land cover classification so that overlying MODIS LST grid cells contained a maximum of $25 \%$ open water. A homogeneous MODIS open water pixel was therefore chosen over the lagoon to the west of the PBP watershed (Fig. 1b). In addition to land cover, MODIS LSTs were assessed in relation to surface albedo and topography, including aspect and slope. The surface albedo was derived from the 16-day combined Terra and Aqua MCD43B3 product, with a resolution of $1 \mathrm{~km}$ (downloaded from http://reverb.echo.nasa.gov/). The topography was derived from the Canadian Digital Elevation Data (CDED) at a scale of 1:50,000 (NR Canada, 2000), which was downloaded from http:// www.geobase.ca/geobase/en/data/cded/index.html. The CDED was resampled to a resolution of $500 \mathrm{~m}$ using the nearest neighbor algorithm in ArcGIS (v10.2.2).

\subsection{Calculating MODIS LST spatial anomalies}

Spatial LST anomalies were calculated as the difference between each daytime and nighttime MODIS LST of each pixel and the regional mean MODIS LST. The regional mean LST was obtained by averaging the available MODIS LSTs of all pixels within the study area. The study area of the anomaly analysis was selected based on the watershed area (Fig. 1b) for which a homogeneous climate was assumed. Erroneous MODIS LST measurements due to incorrect cloud masking are a known issue (Wan, 2008). MODIS LSTs colder than $10^{\circ} \mathrm{C}$ from the regional mean in summer were assumed to be outliers due to the admixing of cloud top temperatures. Summer periods were defined as having regional means of $5{ }^{\circ} \mathrm{C}$ or larger. Altogether 16 MODIS LSTs were identified as outliers during all summer periods and were consequently filtered before anomaly calculation. Anomalies for each pixel were then averaged for longer time periods according to various surface conditions. Surface conditions were specified according to the regional mean, e.g., very cold surface conditions with regional means ranging from -50 to $-20{ }^{\circ} \mathrm{C}$ and warm surface conditions with regional means larger than $5^{\circ} \mathrm{C}$.

\section{Results}

\subsection{MODIS LST performance}

A total of 1320 MODIS LST measurements were compared to in situ LSTs between July 30, 2008 and July 30, 2010. The mean difference (MD) between in situ LSTs and MODIS LSTs was $-1.1{ }^{\circ} \mathrm{C}$ and the total root mean square error (RMSE) was $3.9^{\circ} \mathrm{C}$ over the entire observation period (Fig. 4 and Table 2). Outliers, i.e., MODIS LSTs with a deviation from in situ LSTs larger or equal to $10{ }^{\circ} \mathrm{C}$, made about $2 \%$ of the evaluated 
Table 1

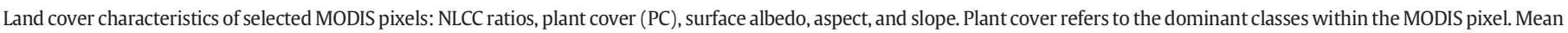
surface albedo was calculated for the snow and lake ice free period from July 12 to August 29, 2010.

\begin{tabular}{|c|c|c|c|c|c|}
\hline \multirow[t]{2}{*}{ Name } & \multirow[t]{2}{*}{ NLCC ratios and description for dominant classes } & \multirow{2}{*}{$\frac{\mathrm{PC}}{[\%]}$} & \multirow{2}{*}{ Albedo } & \multirow[t]{2}{*}{ Aspect } & \multirow[t]{2}{*}{ Slope } \\
\hline & & & & & \\
\hline Wet sedge & $\begin{array}{l}71 \% \text { wet sedge: graminoids and bryoids; wet sedge including cottongrass that is saturated for } \\
\text { a significant part of the growing season, also includes moss and may include }<10 \% \text { dwarf } \\
\text { shrubs }<40 \mathrm{~cm} \text { tall; } 6 \% \text { wetland; } 8 \% \text { tussock graminoid tundra; } 7 \% \text { prostrate dwarf shrub } \\
\text { tundra; } 3 \% \text { bare soil; } 4 \% \text { open water; } 1 \% \text { barren rock }\end{array}$ & $>90$ & 0.17 & 16.6 & 1.9 \\
\hline Bare soil & $\begin{array}{l}\text { 91\% bare soil: bare soil with cryptogam crust-frost boils; unconsolidated barren surfaces } \\
\text { having experienced significant cryoturbation with vegetation cover consisting of graminoids } \\
\text { and cryptogam plants } 5 \% \text { tussock graminoid tundra; } 4 \% \text { prostrate dwarf shrub tundra }\end{array}$ & $2-10$ & 0.16 & 9.1 & 2.3 \\
\hline \multirow[t]{4}{*}{ Ridge } & $43 \%$ bare soil & $2-10$ & 0.17 & 232.2 & 2.5 \\
\hline & $\begin{array}{l}28 \% \text { tussock graminoid tundra: Moist tussock tundra with }<25 \% \text { dwarf shrubs }<40 \mathrm{~cm} \text { tall and } \\
\text { moss }\end{array}$ & $50-70$ & & & \\
\hline & $\begin{array}{l}21 \% \text { prostrate dwarf shrub tundra: Generally dry vegetated cover consisting of prostrate } \\
\text { dwarf shrubs, graminoids and may contain }<10 \% \text { lichen and moss }\end{array}$ & $>50$ & & & \\
\hline & $4 \%$ wet sedge; $3 \%$ sparsely vegetated till-colluvium; $1 \%$ moist to dry non-tussock tundra & & & & \\
\hline Barren rock & $100 \%$ barren: sparse vegetation on nonacidic and calcareous parent material & $<2$ & 0.23 & 232.2 & 4.5 \\
\hline Open water & $100 \%$ open water: areas covered by liquid standing water & & $0.03 \pm 0.01$ & 0 & 0 \\
\hline
\end{tabular}

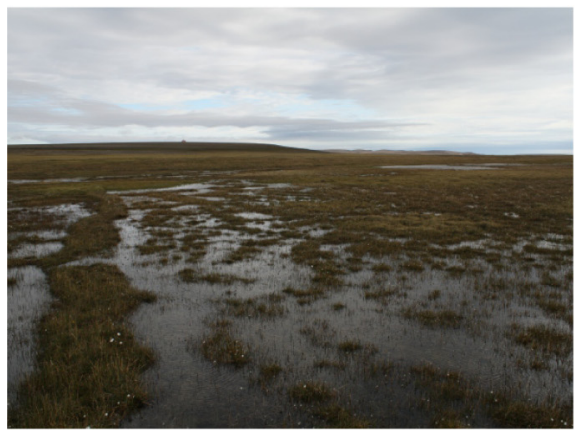

(a) wetland

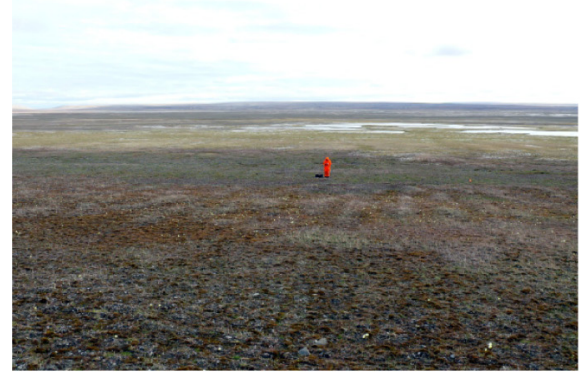

(c) moist to dry non-tussock tundra

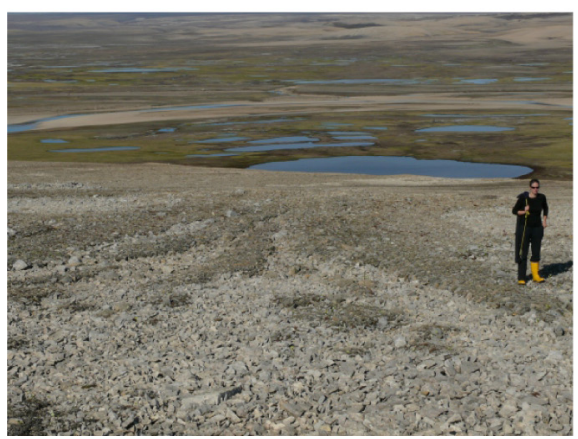

(e) barren rock

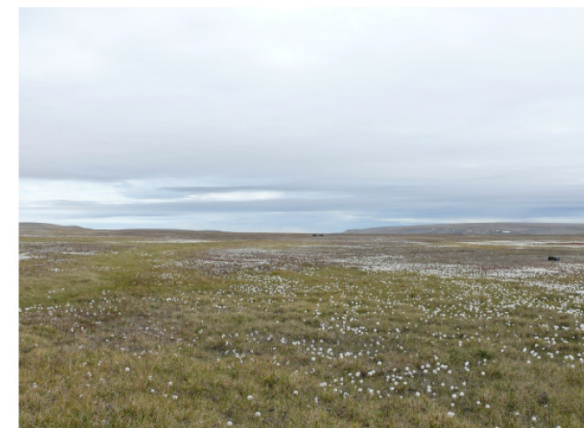

(b) wet sedge

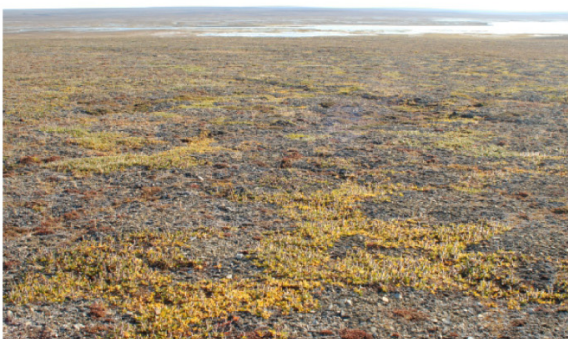

(d) prostrate dwarf shrub tundra

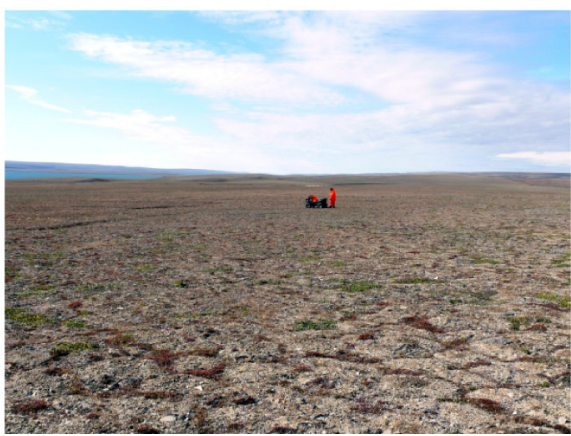

(f) bare soil with cryptogam crust - frost boils

Fig. 3. Photos of different land cover types according to the Northern Land Cover Classification in the Polar Bear Pass watershed. 
Table 2

Comparison of MODIS LST and in situ LST over wet sedge tundra for different periods: number of observations pairs (\# OP), fraction of outliers (OUT), fraction of cloudy MODIS pixels, mean difference (MD), and root mean square error (RMSE). Outliers are defined as MODIS LST deviations larger than $10^{\circ} \mathrm{C}$.

\begin{tabular}{lrrrrr}
\hline Period & \# OP & $\begin{array}{l}\text { OUT } \\
{[\%]}\end{array}$ & $\begin{array}{l}\text { Cloud } \\
\text { fraction } \\
{[\%]}\end{array}$ & $\begin{array}{c}\text { MD } \\
{\left[{ }^{\circ} \mathrm{C}\right]}\end{array}$ & $\begin{array}{l}\text { RMSE } \\
{\left[{ }^{\circ} \mathrm{C}\right]}\end{array}$ \\
\hline Total & 1320 & 2.3 & 37.2 & -1.1 & 3.9 \\
July 30, 2008 to July 30, 2010 & & & & & \\
Snow free & 23 & 8.7 & 69.7 & -3.2 & 3.6 \\
July 30 to August 18, 2008 & 117 & 2.6 & 61.5 & -0.8 & 3.5 \\
June 12 to September 3, 2009 & 111 & 0.9 & 30.8 & 0.2 & 2.9 \\
June 15 to July 31, 2010 & & & & & \\
Snow cover & 611 & 2.3 & 28.9 & -0.7 & 4.0 \\
September 25, 2008 to April 30, 2009 & 153 & 3.3 & 33.9 & -1.1 & 4.3 \\
October 3, 2009 to April 30, 2010 & & & & & \\
Freeze-back & 69 & 7.2 & 52.1 & -4.0 & 5.6 \\
August 19, 2008 to September 24, 2008 & 67 & 0.0 & 53.7 & -3.7 & 4.2 \\
September 4, 2009 to October 2, 2009 & 37 & & & & \\
Snow melt & & & & & \\
May 1, 2009 to June 12, 2010 & 91 & 0.0 & 43.9 & -0.7 & 3.1 \\
May 1, 2010 to June 14, 2010 & 87 & 0.0 & 50 & -1.6 & 3.2 \\
\hline
\end{tabular}

MODIS LST and were all colder than in situ LST. About $44 \%$ of MODIS LST showed a deviation of less than $2{ }^{\circ} \mathrm{C}$. Deviations between 2 and $5{ }^{\circ} \mathrm{C}$ were found for $37 \%$ of the data. The MDs between in situ LSTs and MODIS LSTs were lowest during the snow free period 2009 and 2010 with less than $\pm 1{ }^{\circ} \mathrm{C}$ (Table 2). The snow free period in 2008 only included 3 weeks in July and August when overcast conditions prevailed. This period and the freeze-back periods showed a cold bias of more than $-3.0^{\circ} \mathrm{C}$. The freeze-back period of 2008 showed the largest RMSE of $5.6^{\circ} \mathrm{C}$ whereas the snow free period in 2008 and the freeze-back period in 2008 exhibited the largest fraction of outliers with $9 \%$ and $7 \%$, respectively.

The MODIS LST level 3 product comes with an internal quality flag which indicates the overall quality of the LST value and estimates the LST and emissivity error. For the total observation period, $82 \%$ of MODIS LST used for evaluation showed good data quality with LST errors smaller than $2{ }^{\circ} \mathrm{C}$ and emissivity errors smaller than 0.02 . The remaining $18 \%$ of the MODIS data was identified as LST affected by thin cirrus and/or sub-pixel clouds which can have an LST error of up to $3{ }^{\circ} \mathrm{C}$. RMSE only differed slightly between good quality LST $\left(\right.$ RMSE $\left.=3.8^{\circ} \mathrm{C}\right)$ and cloud-affected LST $\left(\right.$ RMSE $\left.=4.4^{\circ} \mathrm{C}\right)$.

MODIS LST spatial anomalies were calculated from January 1, 2008 to December 31, 2010. For this period, data availability throughout the study area amounted to about $63 \%$. All missing data were not produced due to clouds. Similarly to the MODIS evaluation pixel, $77 \%$ of the MODIS data in the study area were flagged as good quality. The evaluation of MODIS LST with in situ measurements was done for one MODIS pixel. The assessment of spatial anomalies for all pixels present in the study area, however, introduces additional sources of uncertainty through differing viewing conditions for individual pixels. Time of acquisition and viewing angle differed strongly between pixels in the study area on the same day. Spatial anomalies, however, were aggregated over time scales of more than 7 days. For these periods, viewing conditions averaged out and pixels showed a similar distribution of acquisition time and viewing angle.

\subsection{Seasonal variability of MODIS LSTs for different land cover classes}

Seasonal variability in the absolute MODIS LSTs of the five selected land cover classes (LCCs) - these being ridge areas, bare soil, wet sedge, open water, and barren rock surfaces - was assessed for the entire observation period. Fig. 5 shows the patterns of variation during the winter of 2009/2010 and the summer of 2010. Winter LSTs reached down to $-46{ }^{\circ} \mathrm{C}$ and did not vary significantly between LCCs (Fig. 5a). The highest LSTs were found in summer of 2010 , reaching up to $22^{\circ} \mathrm{C}$ for bare soil and up to $14{ }^{\circ} \mathrm{C}$ for open water. During the summer of 2009 predominantly cloudy conditions resulted in lower net radiation, with a mean of $102.2 \mathrm{~W} \mathrm{~m}^{-2}$ which was about $20 \%$ less than in 2008 or 2010 (Table 3). Summer LSTs were therefore coolest in 2009, reaching only $14.4{ }^{\circ} \mathrm{C}$ for bare soil and $10{ }^{\circ} \mathrm{C}$ for open water. Significant LST variations between LCCs were observed during warm synoptic periods in each of the years (Fig. 5b). Such periods were distinct in both 2008 and 2010 between about the beginning of June and the middle of July; they were characterized by little cloud cover, high net radiation, and little or no precipitation. In 2008 and 2010, a sharp drop in both net radiation and air temperature in mid July marked the beginning of a period dominated by overcast conditions with frequent precipitation events and low net radiation, with a consequent reduction in LST variations.

\subsection{Temporal variability of MODIS LST anomalies for different LCCS}

Fig. 6 shows the temporal variability of LST anomalies for individual MODIS pixels selected over different LCCs. Anomalies were grouped into different periods based on the RM, ranging from very cold to very warm average surface conditions (Fig. 6). During very cold surface conditions with RMs between -50 and $-35{ }^{\circ} \mathrm{C}$, the barren rock pixel was the warmest LCC with a mean anomaly of $2.0^{\circ} \mathrm{C}$. For RMs between -35 and $-5{ }^{\circ} \mathrm{C}$ little difference was found between the LCCs. With increasing RM, the LST anomaly of the barren rock class became increasingly negative reaching a low of $-3.5^{\circ} \mathrm{C}$ in 2008 . The largest variations in LST anomalies occurred when the RM was greater than $5{ }^{\circ} \mathrm{C}$. The ridge pixel heated up the most, with a mean anomaly of up to $2.9{ }^{\circ} \mathrm{C}$ in 2009, while barren rock and open water were the coldest. Open water was up to $-11{ }^{\circ} \mathrm{C}$ colder than RM in 2010 and also showed the largest inter-quartile range with about $5{ }^{\circ} \mathrm{C}$. This could be attributed to the presence of sea ice, which lasted well into the summer. Ancillary satellite imagery and aerial photos showed that ice was present on the lagoon until July 11 in 2009 and until July 9 in 2010. The period of RM ranging from -5 to $5{ }^{\circ} \mathrm{C}$ combined the snow melt period in spring and the freeze-back period in autumn. Assessing each period individually, maximum differences of up to $3{ }^{\circ} \mathrm{C}$ were found between the ridge and the bare soil pixel during the thaw periods, and between the ridge and the barren rock pixel during freeze-back. In both cases, bare soil and barren rock were colder than the other LCCs. Although absolute MODIS LSTs showed strong inter-annual variations as described in Section 4.2, the mean inter-annual difference between MODIS LST anomalies was very low with $-0.04{ }^{\circ} \mathrm{C}$ and a standard deviation of $0.7^{\circ} \mathrm{C}$.

\subsection{Spatial patterns of MODIS LST across the PBP watershed}

Warm surface conditions with RM larger than $5{ }^{\circ} \mathrm{C}$ showed the highest temporal and spatial diversity. Fig. 7 shows the MODIS LST anomalies averaged for the period with RM larger than $5{ }^{\circ} \mathrm{C}$ for each pixel in the study area. Mean LST anomalies were grouped into classes with temperature ranges of $2{ }^{\circ} \mathrm{C}$, which yielded four distinct anomaly classes with an average standard deviation of $1.8^{\circ} \mathrm{C}$ (Fig. $7 \mathrm{a}, \mathrm{b}$, and c). The general pattern of warmer and colder areas was the same in each year with only slight inter-annual differences. The year 2010 showed the largest negative LST anomalies (ranging from $-4.5^{\circ} \mathrm{C}$ to $2.5^{\circ} \mathrm{C}$ ), while 2009 showed the smallest range from $-3.1{ }^{\circ} \mathrm{C}$ to $2.6{ }^{\circ} \mathrm{C}$. Mean LST anomalies colder than $-2{ }^{\circ} \mathrm{C}$ were mainly associated with the extensive barren rock surfaces in the north-eastern and north-western parts of the study area (Fig. 7d). These areas had the highest albedos, with values ranging between 0.23 and 0.3 (Fig. 7f). Negative LST anomalies were also present in the western part of the PBP wetland area. This part of the wetland area was characterized by a high areal proportion of ponds and lakes and had a low albedo. The largest positive LST 
2008

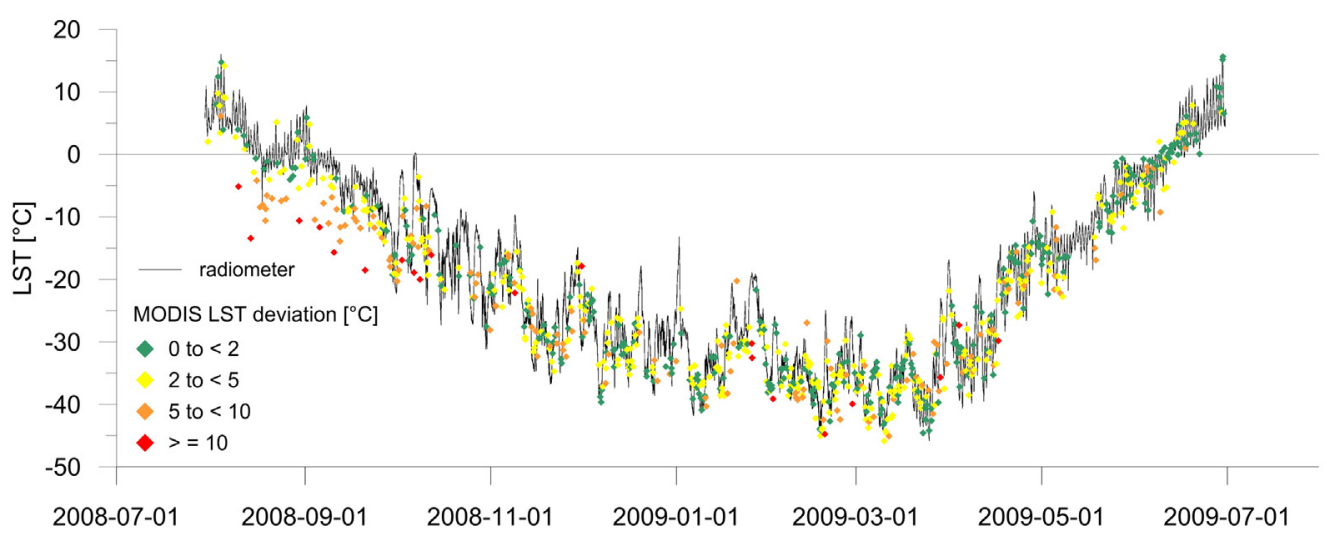

2009

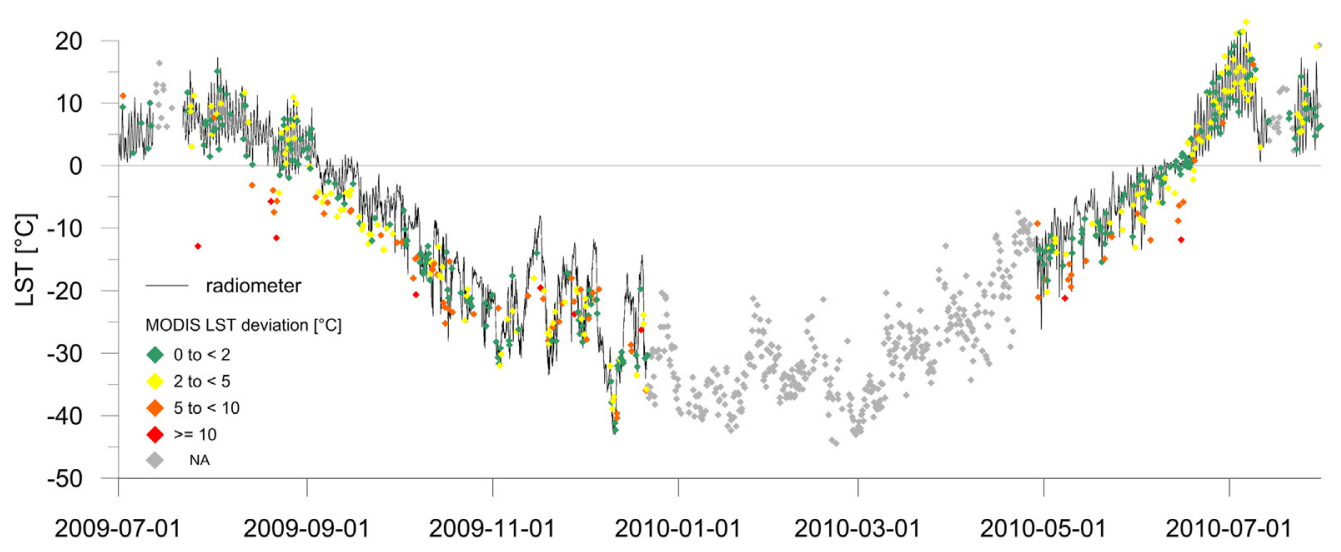

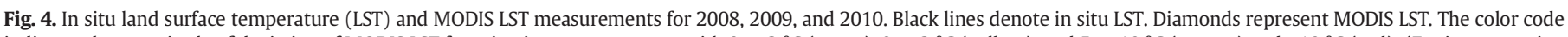

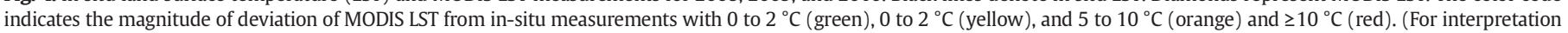
of the references to color in this figure legend, the reader is referred to the web version of this article.)

anomalies (more than $2{ }^{\circ} \mathrm{C}$ ) were recorded for ridge areas north of the wetland. The area was mainly exposed to the south and was comprised of a mixture of LCCs, i.e., a combination of bare soil, prostrate dwarfshrub, and tussock graminoid tundra (Fig. 7d, and e). A similar land cover mosaic could be found in the south-west. Slopes in this area were faced mainly to the north and anomalies ranged between $0{ }^{\circ} \mathrm{C}$ and $2{ }^{\circ} \mathrm{C}$.

\section{Discussion}

\subsection{Uncertainties and errors of MODIS LST evaluation}

The work of this and previous studies strongly suggests that MODIS LST provides reliable data to estimate LST and LST anomalies over a variety of land cover types in Arctic tundra landscapes. The mean difference (MD) between in situ LSTs and MODIS LSTs of $-1.1^{\circ} \mathrm{C}$ in this study is within the range of the measurement uncertainty of both the MODIS and the in situ LSTs. It is also in general agreement with the results from other Arctic studies. Østby et al. (2014) reports an average deviation of MODIS LST of about $3{ }^{\circ} \mathrm{C}$ over the Austfonna ice cap. Accuracies of less than $2.0^{\circ} \mathrm{C}$ for MODIS LST weekly averages were reported in a polygonal tundra landscape composed of dry and wet sedge tundra as well as ponds in Northern Siberia (Langer et al., 2010) and in the barren High-Arctic tundra featuring sparse vegetation on Svalbard (Westermann et al., 2011).

Uncertainties and errors may derive from several issues: (i) the comparison of MODIS LST with plot-scale ground measurements, (ii) erroneous cloud detection within the MODIS processing chain, and (iii) the MODIS inherent clear-sky bias. Uncertainties are inherent in the comparison between MODIS LST and ground-based LST measurements both temporally and spatially. Temporally, the MODIS LST level 3 measurements may be an average of multiple MODIS level 2 observations which means that the measurement time of MODIS LST and in situ LST cannot be exactly matched. Comparing daily averages would have avoided this issue. However, a full daily record of 4 MODIS LST, i.e., nighttime and daytime MODIS LST from both the Terra and the

Table 3

Mean net radiation and air temperature on days with mean regional LST larger than $5^{\circ} \mathrm{C}$. In 2010 , climate data was only available until July 31 .

\begin{tabular}{|c|c|c|c|}
\hline & 2008 & 2009 & 2010 \\
\hline Period & June 25 to August 6 & June 25 to August 28 & June 24 to July 31 \\
\hline Number of observations & 27 & 19 & 28 \\
\hline Net radiation $\left[\mathrm{W} \mathrm{m}^{-2}\right]$ & 123.1 & 102.2 & 131.1 \\
\hline Air temperature $\left[{ }^{\circ} \mathrm{C}\right]$ & 8.6 & 6.5 & 9.4 \\
\hline
\end{tabular}


(a) MODIS LST winter 2009/2010

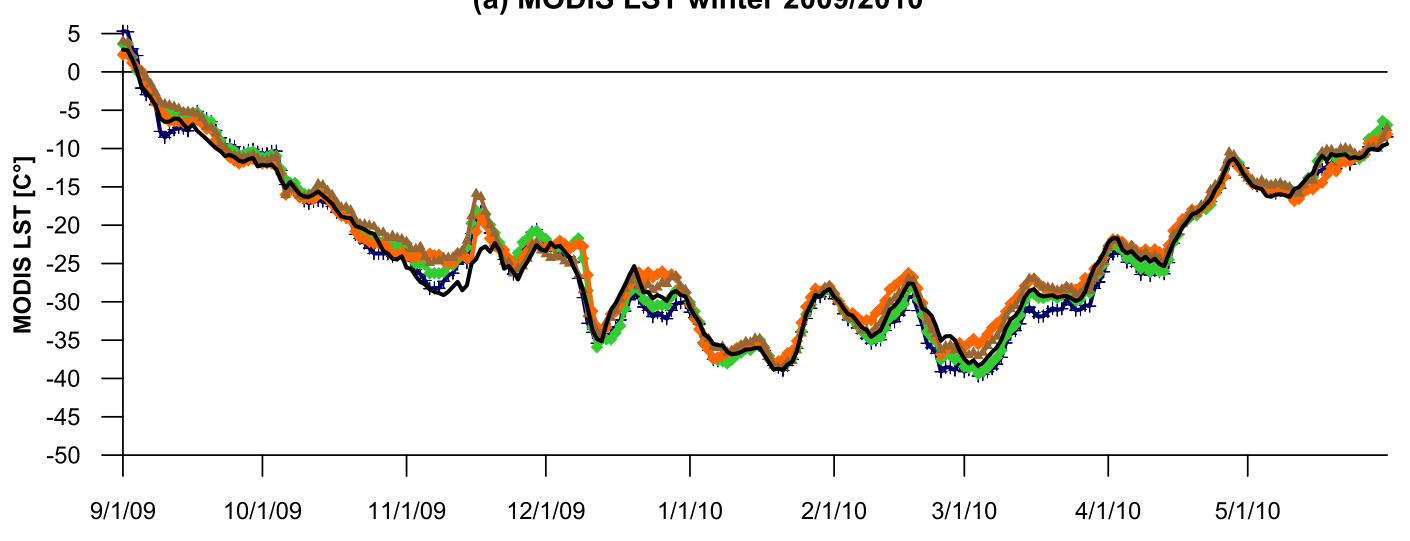

(b) MODIS LST summer 2010

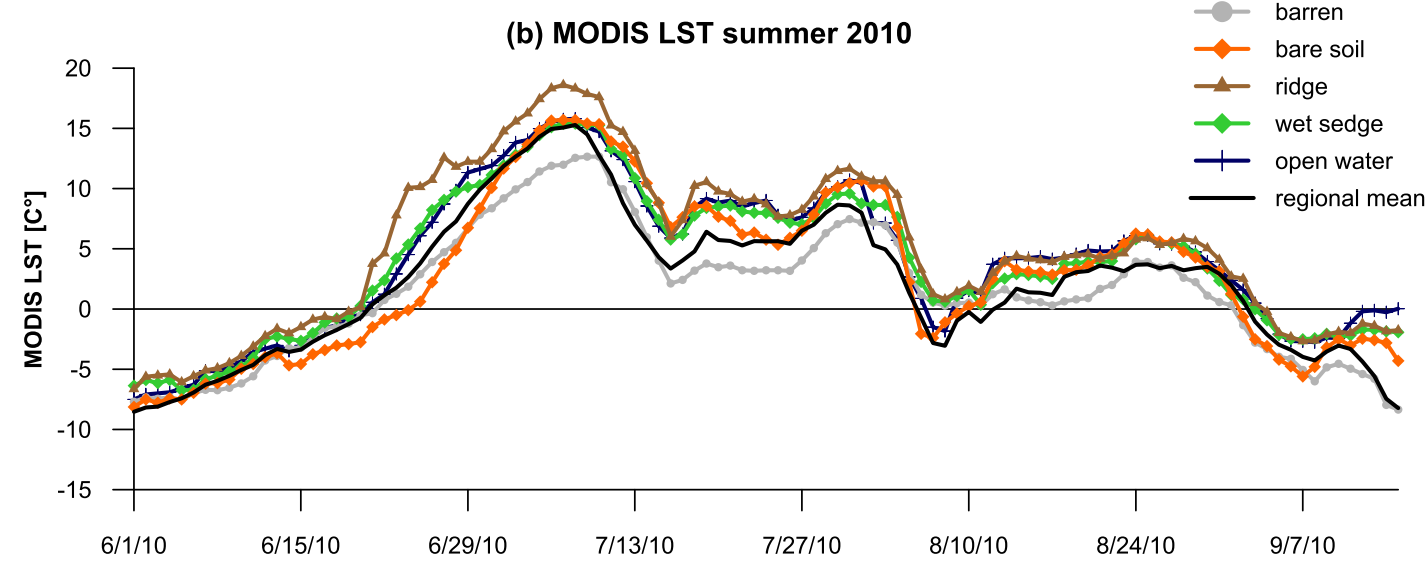

(c) Atmospheric conditions summer 2010

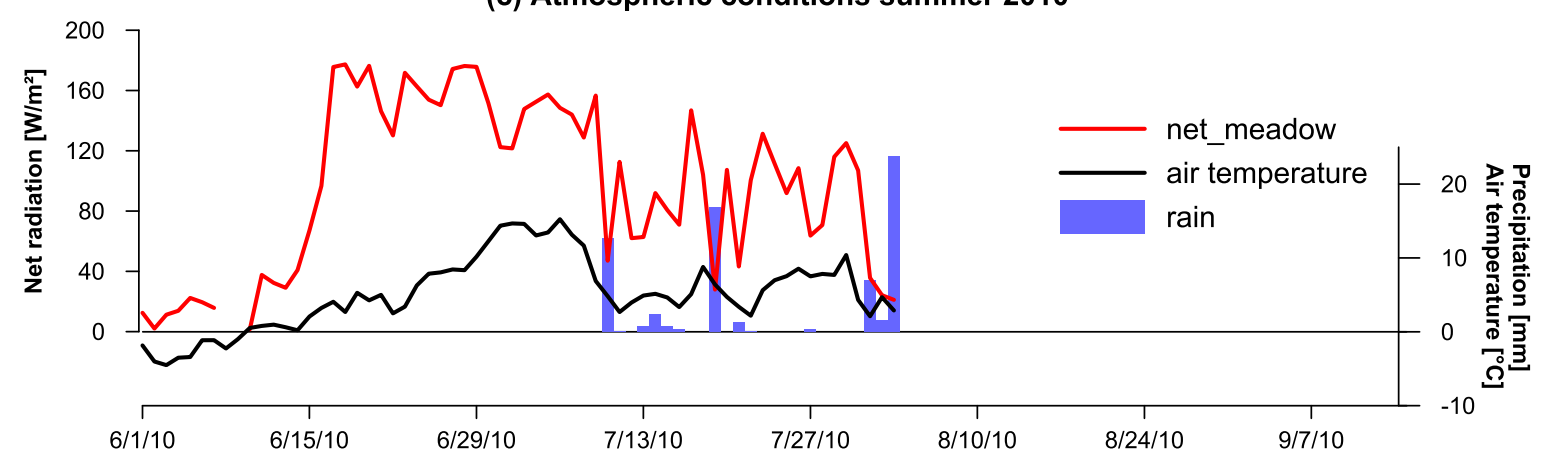

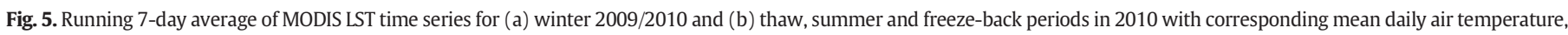
net radiation and precipitation (c).

Aqua satellites, were available for only $40 \%$ of the days throughout the evaluation period. Spatially, sub-grid sized land cover heterogeneities are inevitable for most landscape units due to the large extent of MODIS grid cells within the study area. Subpixel heterogeneity introduces uncertainty into the comparison between MODIS LST and in situ LST through differences in emissivity and temperature between the different land cover types present in the MODIS comparison pixel. Over longer time periods, however, spatial differences are averaged out (Hachem et al., 2012; Langer et al., 2010; Westermann et al., 2011). The low MDs of $\pm 1.0^{\circ} \mathrm{C}$ in the snow free seasons in 2009 and 2010 as well as the snow cover periods are an indicator of this effect. Langer et al. (2010) showed that LSTs of ponds and dry tundra only differed markedly between day and night. Greater contrasts in surface properties between different LCCs (and thus in LSTs) can be expected during snow melt (Westermann et al., 2011). Similarly at Polar Bear Pass, small topographic variations in the otherwise flat wet tundra terrain lead to varying snow depths and thus a patchy snow melt pattern (Assini \& Young, 2012). However, considering the low MDs during snow melt periods spatial differences in LST due to snow were also reduced for the averaging period. Ideally, Wan (2008) recommends taking in situ measurements over large homogeneous sites with dimensions of at least 5 by $5 \mathrm{~km}$, using high-accuracy radiometer measurements at multiple points. Such requirements are, however, extremely difficult to fulfill at Arctic sites, where logistical constraints limit the number of field stations. Hachem et al. (2012) compared MODIS LST to ground and air temperatures over herbaceous and shrub tundra sites across North America. MODIS LST errors found by Hachem et al. (2012) are in the range of errors found in this study. Alternatively to 
MODIS LST anomaly 2008

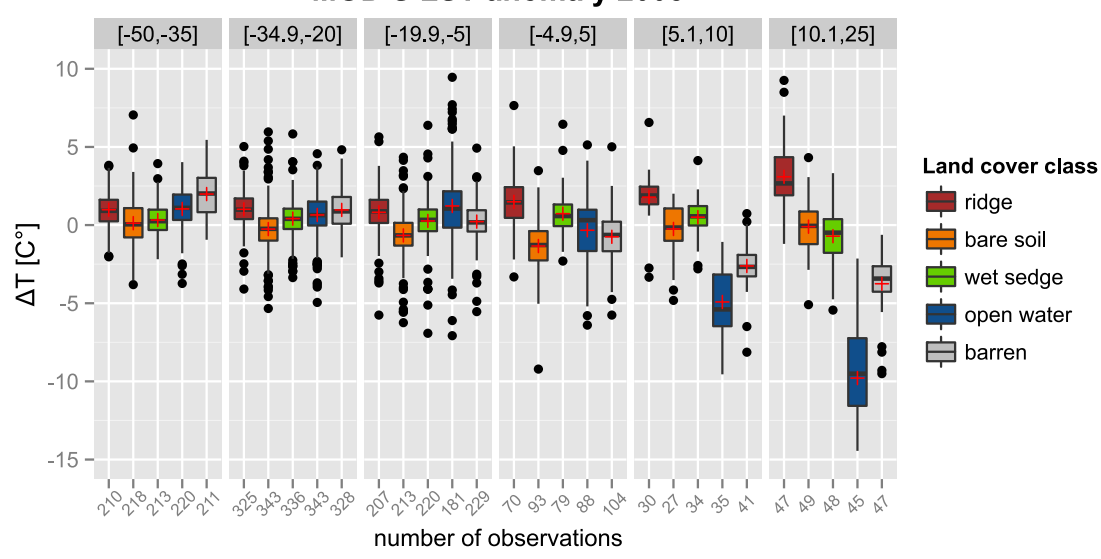

MODIS LST anomaly 2009

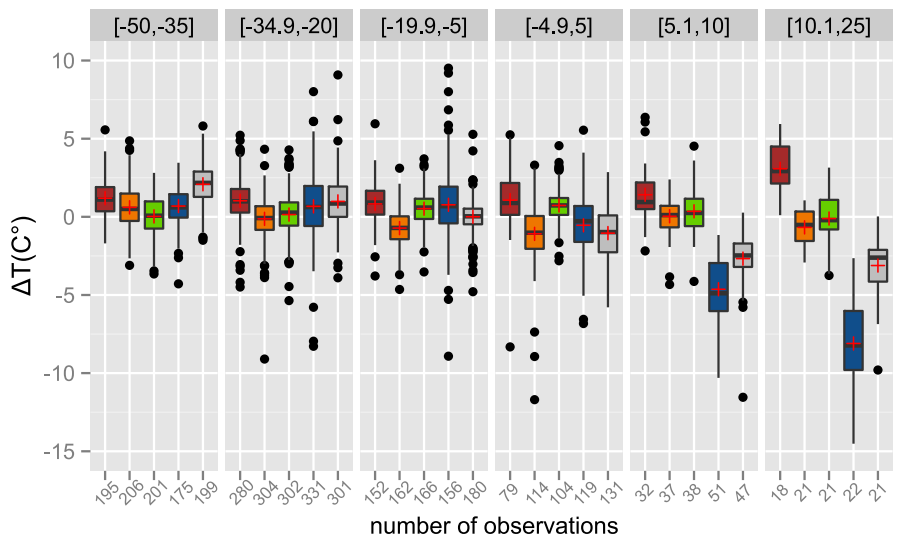

MODIS LST anomaly 2010

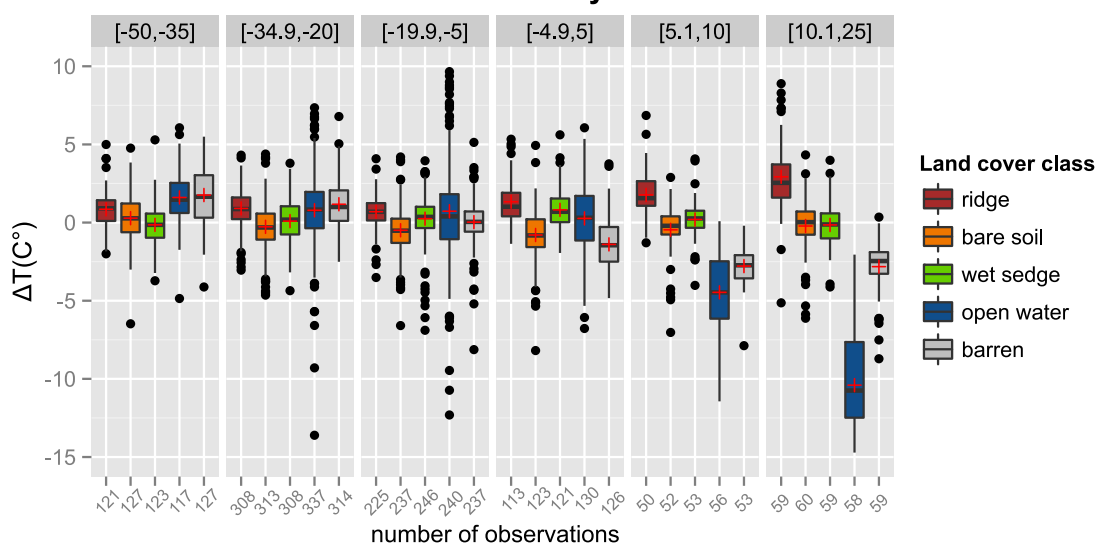

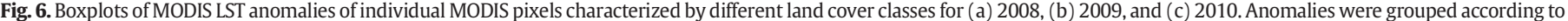

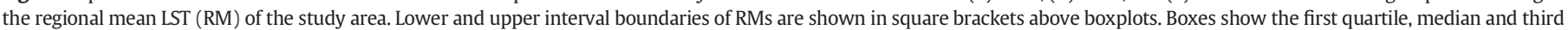

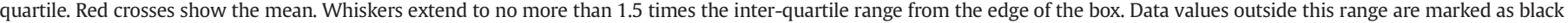
points. (For interpretation of the references to color in this figure legend, the reader is referred to the web version of this article.)

radiometer measurements, measurements of near-surface ground and air temperature might therefore serve as validation data for MODIS LST.

Previous studies have shown that the admixing of cloud top temperatures can cause a cold bias (Liu, Ackerman, Maddux, Key, \& Frey, 2010; Westermann et al., 2011). This can also be seen in our study where MODIS outliers with a deviation of more than $10{ }^{\circ} \mathrm{C}$ are without exception colder than in situ LST. This issue therefore has to be addressed when using MODIS LST to produce temporal averages. Apart from outliers, discrepancies between field and satellite measurements were largest during the freeze-back periods which exhibited significantly colder MODIS LST. The colder MODIS LST may be related to the inherent association of MODIS measurements with clear-sky conditions. Previous studies have noted the seasonality of MODIS LST errors in Arctic environments with a slight warm bias during summer and a strong cold bias in winter (Langer et al., 2010; Østby et al., 2014; Westermann et al., 2011; Westermann et al., 2012). In summer, net radiation is higher under clear skies and warms the surface more than under overcast conditions. In winter, the opposite is the case: long-wave radiation emitted by the earth's surface is lost to the atmosphere under clear skies and the surface thus cools. Under overcast conditions in winter, on the 

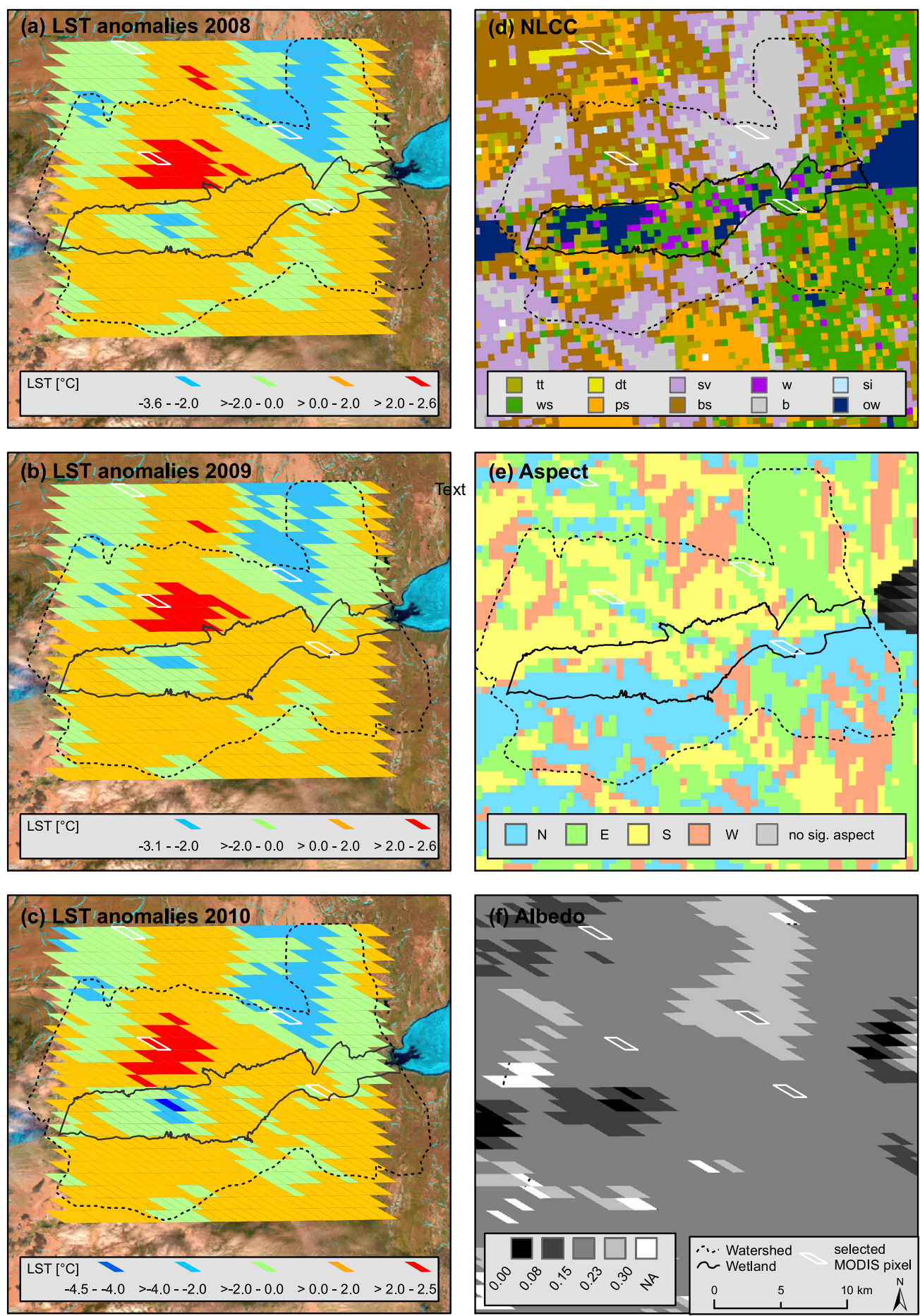

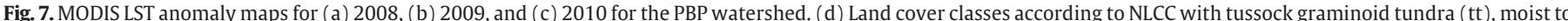

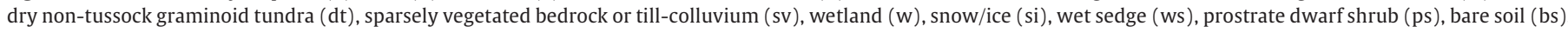

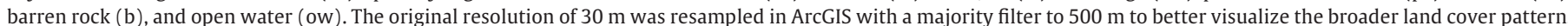

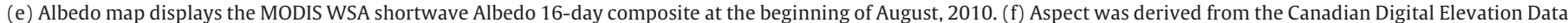
with a resolution of about $50 \mathrm{~m}$ (NR Canada, 2000) (http://www.geobase.ca/geobase/en/data/cded/index.html).

other hand, the long-wave radiation is partly re-emitted back to the earth and consequently warms the surface.

\subsection{Relationship between MODIS LST anomalies and land surface properties}

The greatest spatial diversity in LSTs within our study area occurred during the summer months under warm and dry atmospheric conditions with high levels of net radiation. In summer, wetland areas were coolest compared to the other LCCs. These areas are characterized by a large proportion of open water in the form of ponds, lakes, or inundated wetland surfaces. The moisture supply at the surface is virtually unlimited and causes evaporative cooling due to an increased latent heat flux. Wet sedge tundra, however, did not show the same degree of cooling: although the soil remains saturated in these areas throughout the summer, the moss cover dries out during warm, dry periods, which significantly reduces the latent heat fluxes (Blok et al., 2011; Liljedahl et al., 2011; Muster, Langer, Heim, Westermann, \& Boike, 2012; Oechel \& 
Van Cleve, 1986). Ridge surfaces heated up the most during summer. Ridge surfaces are characterized by well-drained soils so that saturated conditions are limited to a short time span during, and immediately after, snow melt (Young, Assini, Abnizova, \& De Miranda, 2010). Dry surface conditions reduce the latent heat flux in favor of the sensible heat flux and thus increase surface heating. Barren rock surfaces did not heat up as much as either ridge surfaces or bare soil surfaces, but remained about $5{ }^{\circ} \mathrm{C}$ cooler than the regional mean. This may partly be due to differences in surface albedo. The albedo of barren rock surfaces is about $7 \%$ higher than that of bare soil surfaces, so that more of the incoming shortwave radiation is reflected back into the atmosphere and less net radiation is available for heating the surface. Moreover, field observations revealed runoff from the dry, barren rock plateaus, which we attribute to melt water from ground ice. This would provide additional cooling in these areas.

\subsection{Spatio-temporal sensitivity of MODIS LST anomalies}

The sensitivity of MODIS LST anomalies towards land surface properties indicates a high potential of anomaly maps to detect large-scale land cover changes with regard to the surface energy balance. Despite strong differences in precipitation, air temperature and net radiation, LST anomalies displayed a distinct recurrent pattern for the different years with only minor variations. This supports our assumption that the surface thermal pattern is an expression of the land surface characteristics and not of atmospheric conditions. The spatial patterns of MODIS LST anomalies were much broader than might be expected from the 12 different classes of the NLCC. However, with respect to the energy exchange at the earth's surface, different combinations of the latent heat flux, the sensible heat flux, and the ground heat flux may result in similar LSTs as has been shown in the case of barren rock and wetland surfaces. Moreover, the LST of a MODIS pixel represents an average over a large area: spatially dispersed LCCs could not be assessed individually, and local effects of different LCCs within one pixel may have canceled each other out. With respect to land cover change mapping, however, these drawbacks can be addressed by combining MODIS LST measurements with higher resolution optical and radar satellite imagery. The LST anomaly patterns also depend on the choice of the LST anomaly classes, but the general relationships between LSTs and land surface characteristics remain consistent, independent of the exact class boundaries.

The MODIS LST performance over wet sedge tundra is indicative of the overall quality of MODIS LST spatial anomalies throughout the study area. A large source of uncertainty are erroneous cloud top temperatures which can be reasonably filtered out for warm surface conditions. Uncertainties due to viewing conditions were averaged out over longer time periods. This might be different, though, in boreal regions where trees and shrubs are dominant land cover elements that may bias LST estimation due to structural shading, evaporative cooling, or larger surface-air temperature differences (Guillevic et al., 2013).

\section{Conclusions}

Land surface changes due, for example, to a prolongation of the snow-free season, a transition from tundra to shrub or forest, and changes in surface moisture, can be detected from optical and radar satellite imagery. Space-borne radiometric measurements, however, provide direct information on the process of heat exchange between the earth's surface and its atmosphere and can therefore indicate changes in the surface energy balance. The presented study has investigated the accuracy of the MODIS LST/Emissivity Daily L3 Global 1 km V005 product in a Canadian High Arctic permafrost landscape, and its sensitivity to different land cover types ranging from fully vegetated wet sedge tundra to non-vegetated barren rock. The work of this and previous studies strongly suggests that MODIS LST provides reliable data to estimate LST and LST anomalies over a variety of land cover types in
Arctic tundra landscapes. A multi-year analysis revealed robust spatiotemporal patterns of LST anomalies in summer, taking into account different weather conditions and the established LST uncertainties. Summer anomaly classes mainly reflected a combination of albedo and surface wetness which indicates the use of this tool to monitor surface drying and wetting in the Arctic. The presented case study indicates a high potential to use LST anomalies to detect land cover changes in Arctic tundra landscapes as a result of permafrost degradation or climate change. We recommend using the anomaly analysis over time scales of 7 days or more. For shorter time periods, viewing conditions should be considered and corrected if necessary. Additional evaluation of this approach is also needed in boreal regions where structural landscape elements such as trees and shrubs may bias LST due to directional effects. The presented summer LST anomalies can be used as a baseline against which to evaluate past and future changes in land surface properties, in particular with regard to the surface energy balance. A multi-sensor approach combining thermal satellite measurements with high to medium resolution optical and radar imagery therefore promises to be an effective tool for a dynamic, process-based ecosystem monitoring scheme.

\section{Acknowledgments}

This work was supported by the Heinrich Boell Foundation through a stipend awarded to Sina Muster and the Helmholtz Association through a grant (VH-NG 203) awarded to Julia Boike. We thank Britta Kattenstroth, Ute Wollschlaeger and Torsten Sachs for collecting data in the field. We thank Stephan Lange for helping with GIS analysis. This research was partially supported by Natural Sciences and Engineering Research Council (NSERC) and the Canadian Federal IPY-NSERC program with grants to Kathy L. Young. Logistical support was provided by the NRCan - Polar Continental Shelf Program.

\section{References}

ACIA (2005). Arctic climate impact assessment - Scientific report. Cambridge University Press.

AMAP (2011). Snow, Water, Ice and Permafrost in the Arctic (SWIPA). Oslo: Arctic Monitoring and Assessment Programme (AMAP).

Assini, J., \& Young, K. L. (2012). Snow cover and snowmelt of an extensive High Arctic wetland: Spatial and temporal seasonal patterns. Hydrological Sciences Journal, 57, 738-755.

Bhatt, U. S., Walker, D. A., Raynolds, M. K., Bieniek, P. A., Epstein, H. E., Comiso, J. C., Pinzon, J. E., Tucker, C. J., \& Polyakov, I. V. (2013). Recent declines in warming and vegetation greening trends over Pan-Arctic tundra. Remote Sensing, 5, 4229-4254.

Blok, D., Heijmans, M., Schaepman-Strub, G., Van Ruijven, J., Parmentier, F., Maximov, T., \& Berendse, F. (2011). The cooling capacity of mosses: Controls on water and energy fluxes in a Siberian tundra site. Ecosystems, 14, 1055-1065.

Bussières, N. (2002). Thermal features of the Mackenzie Basin from NOAA AVHRR observations for summer 1994. Atmosphere-Ocean, 40, 233-244.

NR Canada (2000). Canadian Digital Elevation Data. Government of Canada, Natural Resources Canada, Earth Sciences Sector, Centre for Topographic Information.

Carroll, M., Townshend, J., DiMiceli, C., Loboda, T., \& Sohlberg, R. (2011). Shrinking lakes of the Arctic: Spatial relationships and trajectory of change. Geophysical Research Letters, 38.

Chapin, F., Sturm, M., \& Serreze, M. e. a. (2005). Role of land-surface changes in Arctic summer warming. Science, 310, 657.

Comiso, J. C. (2003). Warming trends in the Arctic from clear sky satellite observations. Journal of Climate, 16, 3498-3510.

Comiso, J. C. (2006). Arctic warming signals from satellite observations. Weather, 61, 70-76.

Coops, N. C., Wulder, M. A., \& Iwanicka, D. (2009). Large area monitoring with a MODISbased Disturbance Index (DI) sensitive to annual and seasonal variations. Remote Sensing of Environment, 113, 1250-1261.

Dickinson, R. (1983). Land surface processes and climate-Surface albedos and energy balance. Advances in Geophysics, 25, 305-353.

Edlund, S., \& Alt, B. (1989). Regional congruence of vegetation and summer climate patterns in the Queen Elizabeth Islands, Northwest Territories, Canada. Arctic, 42, 3-23.

Euskirchen, E., McGuire, A., \& Chapin, F. S. (2007). Energy feedbacks of northern highlatitude ecosystems to the climate system due to reduced snow cover during 20th century warming. Global Change Biology, 13, 2425-2438.

Friedl, M. (2002). Forward and inverse modeling of land surface energy balance using surface temperature measurements. Remote Sensing of Environment, 79, 344-354.

Gota, K., Royer, A., \& Bussières, N. (1997). Characterization of land surface thermal structure from NOAA-AVHRR data over a northern ecosystem. Remote Sensing of Environment, 60, 282-298. 
Guillevic, P. C., Bork-Unkelbach, A., Gottsche, F. M., Hulley, G., Gastellu-Etchegorry, J. P. Olesen, F. S., \& Privette, J. L. (2013). Directional viewing effects on satellite land surface temperature products over sparse vegetation canopies-A multisensor analysis. IEEE Geoscience and Remote Sensing Letters, 10, 1464-1468.

Hachem, S., Duguay, C., \& Allard, M. (2012). Comparison of MODIS-derived land surface temperatures with ground surface and air temperature measurements in continuous permafrost terrain. The Cryosphere, 6, 51-69.

Hinzman, L. D., Bettez, N. D., \& Bolton, W. R. e. a. (2005). Evidence and implications of recent climate change in Northern Alaska and other Arctic regions. Climatic Change, $72,251-298$.

Hinzman, L. D., Deal, C. J., McGuire, A. D., Mernild, S. H., Polyakov, I. V., \& Walsh, J. E. (2013). Trajectory of the Arctic as an integrated system. Ecological Applications, 23, 1837-1868.

Jin, M., \& Dickinson, R. E. (2010). Land surface skin temperature climatology: Benefitting from the strengths of satellite observations. Environmental Research Letters, 5, 044004.

Jorgenson, M., Racine, C., Walters, J., \& Osterkamp, T. (2001). Permafrost degradation and ecological changes associated with a warming climate in central Alaska. Climatic Change, 48, 551-579.

Jorgenson, M. T., Shur, Y. L., \& Pullman, E. R. (2006). Abrupt increase in permafrost degradation in Arctic Alaska. Geophysical Research Letters, 33.

Langer, M., Westermann, S., \& Boike, J. (2010). Spatial and temporal variations of summer surface temperatures of wet polygonal tundra in Siberia - Implications for MODIS LST based permafrost monitoring. Remote Sensing of Environment, 114, 2059-2069.

Langer, M., Westermann, S., Heikenfeld, M., Dorn, W., \& Boike, J. (2013). Satellite-based modeling of permafrost temperatures in a tundra lowland landscape. Remote Sensing of Environment, 135, 12-24.

Liljedahl, A., Hinzman, L., Harazono, Y., Zona, D., Tweedie, C., Hollister, R., Engstrom, R., \& Oechel, W. (2011). Nonlinear controls on evapotranspiration in Arctic coastal wetlands. Biogeosciences, 8, 3375-3389.

Liu, Y., Ackerman, S. A., Maddux, B. C., Key, J. R., \& Frey, R. A. (2010). Errors in cloud detection over the Arctic using a satellite imager and implications for observing feedback mechanisms. Journal of Climate, 23, 1894-1907.

Mannstein, H. (1987). Surface energy budget, surface temperature and thermal inertia. Remote sensing applications in meteorology and climatology (pp. 391-410). Springer.

Matthes, H., Rinke, A., Miller, P. A., Kuhry, P., Dethloff, K., \& Wolf, A. (2012). Sensitivity of high-resolution Arctic regional climate model projections to different implementations of land surface processes. Climatic Change, 111, 197-214.

Mekis, É., \& Vincent, L. A. (2011). An overview of the second generation adjusted daily precipitation dataset for trend analysis in Canada. Atmosphere-Ocean, 49, 163-177.

Muster, S., Heim, B., Abnizova, A., \& Boike, J. (2013). Water body distributions across scales: A remote sensing based comparison of three Arctic tundra wetlands. Remote Sensing, 5(4), 1498-1523.

Muster, S., Langer, M., Heim, B., Westermann, S., \& Boike, J. (2012). Subpixel heterogeneity of ice-wedge polygonal tundra: A multi-scale analysis of land cover and evapotranspiration in the Lena River Delta, Siberia. Tellus Series B: Chemical and Physical Meteorology, 64.

Nettleship, D. N., \& Smith, P. A. (1975). Ecological sites in northern Canada. Canadian Committee for the International Biological Programme, Conservation Terrestrial-Panel 9.

Oechel, W., \& Van Cleve, K. (1986). The role of bryophytes in nutrient cycling in the Taiga. Forest ecosystems in the Alaskan Taiga (pp. 121-137). Springer.

Olthof, I., Butson, C., Fernandes, R., Fraser, R., Latifovic, R., \& Orazietti, J. (2005). Landsat ETM + mosaic of northern Canada. Canadian Journal of Remote Sensing, 31, 412-419.

Olthof, I., Latifovic, R., \& Pouliot, D. (2008). Circa-2000 Northern Land Cover of Canada. Ottawa, Ontario, Canada: Earth Sciences Sector, Canada Centre for Remote Sensing, Natural Resources Canada.
Østby, T. I., Schuler, T. V., \& Westermann, S. (2014). Severe cloud contamination of MODIS land surface temperatures over an Arctic ice cap, Svalbard. Remote Sensing of Environment, 142, 95-102.

Parry, M. L. (2007). Climate Change 2007: Impacts, Adaptation and Vulnerability: Working Group I Contribution to the Fourth Assessment Report of the IPCC, Volume 4, Cambridge University Press.

Sheard, J., \& Geale, D. (1983). Vegetation studies at Polar Bear Pass, Bathurst Island, N.W.T I. Classification of plant communities. Canadian Journal of Botany, 61, 1618-1636.

Smith, L., Sheng, Y., MacDonald, G., \& Hinzman, L. (2005). Disappearing Arctic lakes. Science, 308, 1429.

Soliman, A., Duguay, C., Saunders, W., \& Hachem, S. (2012). Pan-Arctic land surface temperature from MODIS and AATSR: Product development and intercomparison. Remote Sensing, 4, 3833-3856.

Sturm, M., Racine, C., \& Tape, K. (2001). Climate change: Increasing shrub abundance in the Arctic. Nature, 411, 546-547.

Wan, Z. (2006). MODIS land surface temperature products users' guide. Santa Barbara, CA: Institute for Computational Earth System Science, University of California (http:// www.icess.ucsb.edu/modis/LstUsrGuide/usrguide.html).

Wan, Z. (2008). New refinements and validation of the MODIS land-surface temperature/ emissivity products. Remote Sensing of Environment, 112, 59-74.

Wan, Z., \& Dozier, J. (1996). A generalized split-window algorithm for retrieving landsurface temperature from space. IEEE Transactions on Geoscience and Remote Sensing, 34, 892-905.

Wan, Z., \& Li, Z. L. (1997). A physics-based algorithm for retrieving land-surface emissivity and temperature from EOS/MODIS data. IEEE Transactions on Geoscience and Remote Sensing, 35, 980-996.

Watts, J., Kimball, J., Jones, L., Schroeder, R., \& McDonald, K. (2012). Satellite microwave remote sensing of contrasting surface water inundation changes within the ArcticBoreal region. Remote Sensing of Environment, 127, 223-236.

Westermann, S., Langer, M., \& Boike, J. (2011). Spatial and temporal variations of summer surface temperatures of High-Arctic tundra on Svalbard-Implications for MODIS LST based permafrost monitoring. Remote Sensing of Environment, 115, 908-922.

Westermann, S., Langer, M., \& Boike, J. (2012). Systematic bias of average winter-time land surface temperatures inferred from MODIS at a site on Svalbard, Norway. Remote Sensing of Environment, 118, 162-167.

Wolfe, R. E., Nishihama, M., Fleig, A. J., Kuyper, J. A., Roy, D. P., Storey, J. C., \& Patt, F. S. (2002). Achieving sub-pixel geolocation accuracy in support of MODIS land science. Remote Sensing of Environment, 83, 31-49.

Woo, M., \& Young, K. (2006). High Arctic wetlands: Their occurrence, hydrological characteristics and sustainability. Journal of Hydrology, 320, 432-450.

Woo, M. K., \& Young, K. L. (2014). Disappearing semi-permanent snow in the High Arctic and its consequences. Journal of Glaciology, 60, 192-200.

Yoshikawa, K., \& Hinzman, L. D. (2003). Shrinking thermokarst ponds and groundwater dynamics in discontinuous permafrost near Council, Alaska. Permafrost and Periglacial Processes, 14, 151-160.

Young, K., Assini, J., Abnizova, A., \& De Miranda, N. (2010). Hydrology of hillslope-wetland streams, Polar Bear Pass, Nunavut, Canada. Hydrological Processes, 24, 3345-3358.

Young, K., \& Labine, C. (2010). Summer hydroclimatology of an extensive low-gradient wetland: Polar Bear Pass, Bathurst Island, Nunavut, Canada. Hydrology Research, 41 492-502.

Zhang, X., Friedl, M. A., Schaaf, C. B., \& Strahler, A. H. (2004). Climate controls on vegetation phenological patterns in northern mid- and high latitudes inferred from MODIS data. Global Change Biology, 10, 1133-1145. 